\title{
Cultural Adaptation and Reliability Analysis of the Modified Dyspnea Index for the Brazilian Culture ${ }^{1}$
}

\author{
Cinthya Tamie Passos Miura² \\ Maria Cecilia Bueno Jayme Gallani3 \\ Gabriela de Barros Leite Domingues ${ }^{2}$ \\ Roberta Cunha Matheus Rodrigues ${ }^{4}$ \\ James K. Stoller ${ }^{5}$
}

\begin{abstract}
This study aims to present the cross-cultural adaptation process of the Modified Dyspnea Index to the Brazilian culture and to investigate its content validity and reliability. This process included the steps of translation, back translation and review by two experts to assess semantic, conceptual, idiomatic, cultural and metabolic equivalence. The Index of Content Validity was used to evaluate the extent of inter-observer agreement. A Guide to implement the Modified Dyspnea Index was developed and validated. Two different professionals assessed the reliability of the Brazilian version of the Modified Dyspnea Index, according to the inter-observer equivalence criterion, with 31 patients, indicating a Kappa coefficient $=0.960(p<0.001)$. In conclusion, the Brazilian version of MDI presented evidence of interobserver equivalence when applied by different health professionals in the population of cardiac patients.
\end{abstract}

Descriptors: Dyspnea; Coronary Disease; Reproducibility of Results; Validation Studies.

\footnotetext{
${ }^{1}$ Supported by CAPES, FAPESP and FAEPEX-UNICAMP.

2 Physical Therapist, Master's Student, Nursing Graduate Program, Faculdade de Ciência Médicas, Universidade Estadual de Campinas, SP, Brazil. E-mail: cinthyamiura@gmail.com, e-mail: gabrielafisio@yahoo.com.br.

${ }^{3}$ RN, Free Lecture, Associate Professor, Faculdade de Ciências Médicas, Universidade Estadual de Campinas, SP, Brazil. E-mail: ceciliag@fcm.unicamp.br.

${ }^{4}$ RN, Free Lecture, Associate Professor, Faculdade de Ciências Médicas, Universidade Estadual de Campinas, SP, Brazil. E-mail: robertar@fcm.unicamp.br.

${ }^{5}$ MD, Institute Chair, Education Institute, Cleveland Clinic Main Campus, Cleveland, Ohio, The United States. E-mail: stollej@ccf.org.
}

Corresponding Author:

Maria Cecília Bueno Jayme Gallani

Rua Dr. Emílio Ribas, 800 Ap. 9

CEP: 13025-141 Campinas, SP, Brasil

E-mail: ceciliag@fcm.unicam.br 


\title{
Adaptação cultural e análise da confiabilidade do instrumento Modified Dyspnea Index para a cultura brasileira
}

Este estudo apresenta o processo de adaptação cultural do Modified Dyspnea Index para a cultura brasileira e a avaliação de sua validade de conteúdo e confiabilidade. Esse processo incluiu as etapas de tradução, retrotradução e avaliação da equivalência semântica, idiomática, conceitual, cultural/experimental e metabólica. Utilizou-se o Índice de Validade de Conteúdo para avaliar a proporção de concordância entre os juízes. Foi desenvolvido e validado um roteiro para nortear a aplicação do Modified Dyspnea Index. Dois diferentes profissionais avaliaram a confiabilidade da versão brasileira do Modified Dyspnea Index, de acordo com o critério da equivalência interobservador, em 31 pacientes, apontando para um coeficiente Kappa=0,960 $(p<0,001)$. A versão brasileira do Modified Dyspnea Index apresentou provas de equivalência interobservador em amostra de pacientes cardíacos.

Descritores: Dispnéia; Cardiopatia Coronariana; Confiabilidade e Validade; Estudos de Validação.

\section{Adaptación cultural y análisis de la confiabilidad del instrumento Modified Dyspnea Index para la cultura brasileña}

\begin{abstract}
Este estudio presenta el proceso de adaptación cultural del Modified Dyspnea Index para la cultura brasileña y la evaluación de su validad de contenido y confiabilidad. Este proceso incluyó las etapas de traducción, retrotraducción y evaluación de la equivalencia semántica, idiomática, conceptual, cultural/experimental y metabólica. El Índice de Validad de Contenido fue utilizado para evaluar la proporción de concordancia entre los jueces. Fue desarrollado y validado un guión para orientar la aplicación del Modified Dyspnea Index. Dos diferentes profesionales evaluaron la confiabilidad de la versión brasileña del Modified Dyspnea Index, de acuerdo con el criterio de la equivalencia interobservador, en 31 pacientes, apuntando para un coeficiente Kappa=0,960 ( $<<0,001)$. La versión brasileña del Modified Dyspnea Index presentó pruebas de equivalencia interobservador en una muestra de pacientes cardíacos.
\end{abstract}

Descriptores: Disnea; Enfermedades Coronaria; Reproducibilidad de Resultados; Estudios de Validación.

\section{Introduction}

Cardiovascular diseases (CVD) represent an important cause of morbidity and mortality worldwide. In this context, dyspnea is one of the most important symptoms, characterized as a subjective experience of respiratory discomfort, generally triggered by physical exercise, which consists in sensations that are qualitatively different and vary in intensity ${ }^{(1-2)}$. Causes of dyspnea are multiple (physiological, psychological, social and environmental) and the symptom may elicit important physiological and behavioral responses(3)

The study of dyspnea is complicated, due to the difficulties to precisely define the physical stimulus that triggers it. In an attempt to assess and quantify dyspnea more objectively, different instruments have been developed, including structured interviews, self-report questionnaires, visual analogue scales, which assess dyspnea in both qualitative and quantitative terms.

Specifically in the context of cardiopulmonary diseases, dyspnea has been assessed using instruments that measure the intensity of the symptom: the Horizontal Visual Analogue Scale (HVAS) ${ }^{(4)}$, Borg Scale ${ }^{(5)}$, Modified Borg Scale ${ }^{(5)}$, and the Numeric Rating Scale(6); and instruments that assess the impact or limitations imposed by dyspnea: Cardiovascular Limitations and Symptoms 
Profile (CLASP) ${ }^{(7)}$, Chronic Heart Failure Questionnaire dyspnea subscale (CHQ-D) ${ }^{(8)}$; the Oxygen Cost Diagram $(\mathrm{OCD})^{(9)}$ and the Baseline Dyspnea Index $(\mathrm{BDI})^{(10)}$.

In 1986, the Modified Dyspnea Index (MDI) was proposed, as an adaptation of the BDI, which incorporated additional criteria for evaluation of dyspnea, contributing to the greater accuracy of the measure ${ }^{(11)}$.

The MDI was developed in English, focused on the North American culture, and has been applied in research involving patients suffering from various respiratory disorders $^{(12-13)}$.

Applying the MDI in the Brazilian context requires, however, methodological procedures that permit its cultural adaptation - a complex process, which involves steps much more elaborated than the mere translation of the instrument ${ }^{(14)}$. To accomplish the adaptation, the researcher must consider the cultural differences in health perception, taking into account the language, cultural context and lifestyle of the target population ${ }^{(14-15)}$.

This research aims to present the cross-cultural adaptation process of the Modified Dyspnea Index to the Brazilian culture, as well as the analysis of its content validity and reliability.

\section{Materials and Method}

\section{Setting}

The study was carried out at an inpatient cardiology unit of a large university hospital within the state of São Paulo.

\section{Subjects}

Study participants were male or female patients, over 18 years of age, admitted to the unit with a medical diagnosis of cardiovascular disease and complaining of dyspnea. Patients with cognitive deficits and difficulties to understand the questionnaires were excluded.

\section{The process of cultural adaptation}

The first step in the cross-cultural adaptation process was to obtain the formal consent of the original author of the instrument.

\section{Translation to Portuguese}

The first step for the cross-cultural adaptation was to translate the questionnaire from English to Portuguese, which was done by two independent translators, who were qualified professionals for whom English was their native language. As recommended, one of the translators was informed about the instrument objectives and concepts, while the other elaborated the translation without previous knowledge on this information(14-16). Each translator produced a version of the translation, including comments and suggestions regarding specific phrases, discarding uncertainties, along with foundations for the final choices(17).

The researchers compared both versions until they reached a consensus( ${ }^{(17)}$. This procedure facilitated conceptual translation, also guaranteeing the elimination of errors and biased interpretations ${ }^{(16)}$.

\section{Back-translation}

As also recommended, the final translated version obtained in the previous step was then back-translated to the original language (English) by two other translators. These translators were native speakers of English (language of the original instrument), bilingual, and worked independently, thus producing two independent back-translated versions (RT1 and RT2) ${ }^{(14,16-18)}$.

The goal of back-translation is data review and verification of possible dubious interpretations of the new version, thereby further guaranteeing the quality of the study instrument's cross-cultural adaptation ${ }^{(14,17)}$.

\section{Content validity}

As described ${ }^{(14,16-17)}$, to assess equivalences between the translated version of the MDI (to Portuguese) and the original MDI, five criteria had to be reviewed:

1. Semantic Equivalence: assessed whether the meaning of each item was maintained after translation to the language of the target culture ${ }^{(14,17)}$.

2. Idiomatic Equivalence: identifies difficulties to translate colloquial expressions in a given language ${ }^{(14,17)}$.

3. Cultural/ Experimental Equivalence: assessment that attempts to identify if the terms used in the original version are coherent with the target population's experiences $^{(14,17,19) \text {. }}$

4. Conceptual Equivalence: assesses whether the situations evoked or pictured in the items actually assess the impact dyspnea causes in cardiac patients ${ }^{(14,17)}$.

5. Metabolic Equivalence: to assess if all culturally nonadequate activities in the translated version can be considered metabolically equivalent to the activities from the original MDI version.

In this context, content validity was conducted in two phases: 1 . Review of semantic, idiomatic, conceptual and cultural equivalence of the translated version and 
2. Assessment of metabolic equivalence. For each of these assessments, expert committees were constituted (totaling three commissions), each with a specific task in the validation process.

\section{Expert committee for review of semantic, idiomatic, conceptual and cultural/experimental equivalence}

In this first review, a committee comprised of different bilingual experts regarding dyspnea assessment and measurement was invited to review and compare the final translations obtained in Portuguese and the backtranslations. This process was intended to assure that the final translated version preserved the meaning of the original version in English (i.e. semantic and idiomatic equivalence), and also that the situations mentioned or portrayed in the items actually assessed the impact of dyspnea and whether they were culturally pertinent for the target population (that is, conceptual and cultural/experimental equivalence) ${ }^{(14,16,18-19)}$. The expert committee comprised three professionals experienced in care delivery to cardiac patients (nurse, physician and physiotherapist), one researcher specialized in research methodology and one linguist. Each member of the expert committee was informed about the implied measures and concepts and received an instrument, specifically constructed to guide the assessment.

\section{Committee for review of metabolic equivalence}

The initial assessment by the first expert committee identified uncommon activities for the target population, suggesting other ones to replace them. For the replacement, the Ainsworth Compendium adapted by Farinatti ${ }^{(20)}$, which discusses the metabolic equivalents of different physical activities, was consulted. A second committee was then constituted to assess metabolic equivalence between the suggested activities and those from the original instrument, as the latter were related to the physical activity levels that triggered symptoms. This expert committee comprised one physical educator experienced in exercise physiology and one physiotherapist.

\section{Quantification of content validity}

As recommended(21-22), besides the qualitative assessment of equivalences, this study also quantified the judgment of the MDI. In this step, the experts' agreement level is evaluated in the assessment of each item, generating an Index of Content Validity - CVI. The number of experts needed for this assessment step, as well as the necessary agreement proportion to establish content validity can be decided on by applying the standard error of proportion. A minimum of 3 to 5 specialists is recommended. To interpret the representativeness of the agreement levels, the criterion proposed by Lynn ${ }^{(21)}$ was adopted, according to which, considering an 0.05 significance level, for four to five experts, all should agree with the assessment of the item to be considered valid (CVI=1). A CVI $\leq 0.75$ implies the automatic review of the item, as it means that at least one of the judges did not assess at least one of the equivalences under analysis as adequate.

The MDI was conceived for health professionals to answer the instrument, based on the patient assessment. Hence, items are not formulated as questions, which can make it difficult to reproduce different observers' scores. Thus, before applying the pretest of the final translated MDI version, the development of a user's guide was proposed to standardize the MDI administration and scoring among different professionals.

\section{Content validity of the User's Guide MDI for Application of the MDI}

Expert committee to assess the User's Guide for Application the MDI

The instrument created to guide professionals when applying the Brazilian version of the MDI was assessed by a new expert committee comprised by four professionals: two cardiologists with extensive experience in clinical care to cardiac patients, one nurse with experience in cardiology and one physiotherapist specialized in the cardiorespiratory area. Then, the assessments were quantified according to the $\mathrm{CVI}^{(21)}$.

\section{Modified Dyspnea Index (MDI)}

The MDI proposes the assessment of individuals according to three components: Functional Impairment (the extent to which the shortness of breath impairs the accomplishment of domestic and/or occupational activities), Magnitude of Task (the task threshold at which the presence of dyspnea becomes evident to the patient) and Magnitude of Effort (the energy with which individuals can perform their maximum task) $)^{(11-12)}$.

When defining the magnitude of task and effort, the instrument deliberately distinguishes the threshold of performed task, when dyspnea first occurs, and the maximum task performed, despite the presence of dyspnea. As some patients continue to perform even after the start of dyspnea, attempts are made to 
distinguish, through the instrument, the maximum task and the most exhausting task the patient manages to. To quantify the Magnitude of Effort, the task threshold is considered, foreseeing the possibility that the subject will make little effort to reach the threshold at which dyspnea is triggered, but considerable effort to overcome the problem. The Magnitude of Task, in turn, is assessed through the task threshold, considering patients' tendency to underestimate their capacity to perform the most exhausting task. The use of the task threshold to measure the magnitude of task, hence, avoids the risk that patients will underestimate their capacity ${ }^{(11)}$.

Two separate scores inform the rating of Functional Impairment: one to designate functional impairment at home and one for the workplace. These two assessments are later combined to achieve the composite score of functional impairment, which ranges from zero to four. The total score ranges from zero to 12 , reached by adding up the scores (from zero to four) for each MDI component (task, effort and function). The lower the score, the more severe the dyspnea(11).

\section{Pretest of the MDI and of the User's Guide to implement the MDI in the target population}

The final versions of the instruments (MDI and the User's Guide for Implementation of the MDI) underwent pilot testing with two pretests in a small number of individuals to evaluate the accuracy and practicality in order to confirm that all questions were understandable, also verifying practical aspects of its application ${ }^{(15-}$ 16). The first pretest involved assessing understanding of the User's Guide by six patients with dyspnea complaints, hospitalized at a specialized cardiology unit. All patients expressed presented difficulties to understand the questions in the User's Guide. Based on this pilot experience, the User's Guide was redesigned and again assessed by the expert committee (described under item 2.5). Then, a second pretest was done, using the reformulated version of the User's Guide to implement the MDI, involving eight patients hospitalized at the abovementioned unit. In the second pretest, the instrument application time was verified(14).

\section{Pretest of the MDI and the User's Guide among health professionals}

This step comprised the assessment of the MDI and its User's Guide practicability by health professionals who were naïve to the instrument ${ }^{(23)}$. The MDI was applied to six patients at the above described hospitalization units, by six professionals (three physiotherapists and three nurses), using the User's Guide to implement the MDI.

\section{Reliability Assessment}

Reliability was assessed according to the interobserver equivalence criterion, using the Kappa coefficient to assess the agreement level between two health professionals (one nurse and one physiotherapist) in partial and total MDI scoring. Thirty-one patients were assessed at a specialized cardiology unit of a large university hospital in the interior of São Paulo State.

\section{Data analysis}

The collected data were inserted in an electronic worksheet (Excel, 2003) and transferred to SPSS 15.0 for Windows for description and analysis of inter-observed agreement, using the Kappa Coefficient. Statistical significance was set at $p \leq 0.05$.

\section{Ethical Aspects}

Approval for the project was obtained from the local Research Ethics Committee. All participants signed the Free and Informed Consent Term, in accordance with National Health Council Resolution 196/6.

\section{Results}

Experts Committee I (Assessment of Semantic, Idiomatic, Conceptual and Cultural/Experimental Equivalence of MDI)

The analysis of the quantitative inter-rater agreement on the semantic and idiomatic equivalences appointed a mean CVI of $0.64( \pm 0.23)$, against $0.88 \%$ $( \pm 0.19)$ on conceptual equivalence. Therefore, items with CVI $<1$ were modified, ranging from replacements of words to structural alterations in some phrases, such as: scheme replaced by activity, exhausting by tiring, slowly by "slower", realistically by really, too breathless by a lot of shortness of breath, professional (job) activities by work activities, to take a desk by administrative activities, hobby by leisure activities, motionless by without moving, among others.

Regarding the term "dyspnea" the use of the term "shortness of breath" was standardized across the text, anticipating the technical term shortness of breath/ dyspnea, allowing the study population's understanding and, at the same time, preserving the expression that designates the symptom best.

\section{Experts Committee II (Assessment of Metabolic Equivalence)}

The experts considered some activities as uncommon habits for the Brazilian population (going to 
baseball games, going to the theater). On this basis, they suggested the replacement of these activities by other metabolic equivalents of task ${ }^{(20)}$, (baseball by soccer and going to the theater by going to church).

Moreover, in Grade 1 (light activities) of the Magnitude of Task assessment Criterion, "shaving" was replaced by "brushing one's teeth" in order to eliminate any gender bias.

\section{Experts Committee III (Assessment of the User's Guide to implement the MDI)}

Initially, the mean CVI for the Brazilian version of the User's Guide was 0.95 ( \pm 0.10$)$. After reformulating the User's Guide, the final mean CVI was $0.89( \pm 0.16)$, after accepting all of the committee's suggestions.

To clarify the Magnitude of Task assessment Criterion, specific examples of heavy and light loads were provided: 1- a newborn; 2- two large bags of rice; 3- a large bag of dog food. These examples attend to the metabolic equivalence criteria according to Farinatti(20).

\section{Pretest in target population}

The final version of the User's Guide to implement the MDI and the Brazilian version of the MDI were pretested in a sample of eight patients, whose features were: female $62.5 \%$, Mean age 57.5 ( $(11.7)$ years, Mean years of education $5.1( \pm 3.6)$ years, Mean individual monthly income US\$ 444.25 ( \pm 325.78$)$ and mean family income US\$ 651.57 ( \pm 236.93 ). Most interviewees were professionally inactive (62.5\%). The most frequent medical diagnoses were: Hypertension $(37.5 \%)$, Decompensated congestive heart failure (25.0\%) and Acute myocardial infarction (25.0\%).

The mean time required to apply the instrument was 15 minutes. All sample patients could easily understand the reformulated version of the instrument.

\section{Pretest among health professionals}

The final version of the User's Guide to implement the MDI and the Brazilian MDI version were pretested by a sample of health professional. Some scoring difficulties were evidenced in the three MDI dimensions.

When assessing the instruments' practicability, $83.3 \%$ of professionals considered both instruments understandable and reported easiness to mark answers on the MDI. Fifty percent of the professionals, however, mentioned that the instructions formulated in User's Guide to implement the MDI are not easily understood.

\section{Reliability Assessment - Inter-Observer Equivalence}

Inter-observer equivalence of the Brazilian MD version was assessed by administering the instrument to 31 subjects, characterized as follows: Female $61.3 \%$; Caucasian 87.1\%; Mean age $55.0( \pm 15.4)$ years, Mean years of education $6( \pm 5.6)$ years. Mean individual and family monthly income: US\$ $533.10( \pm 592.33)$ and US\$ 1066.20 ( \pm 977.35$)$, respectively, and Professionally inactive $51.7 \%$. The most frequent medical diagnosis were: Hypertension (58.1\%), Acute coronary syndrome $(32.3 \%)$, and Decompensated congestive heart failure (22.6\%).

For this analysis, two health professionals were requested to simultaneously apply the instruments and score patients in a totally independent way. Agreement analysis of the observers' partial and total scores appointed Kappa coefficients ranging between 0.946 and 1.000, evidencing inter-observer equivalence (Table 1).

Table 1 - Kappa statistics to assess inter-observer agreement when applying the Brazilian version of the MDI

\begin{tabular}{lcc}
\hline & Kappa statistics & P-value \\
\hline Functional Impairment at Work & 1.000 & $<0.0001$ \\
Functional Impairment at Home & 0.946 & $<0.0001$ \\
Composite Functional grade & 0.947 & $<0.0001$ \\
Magnitude of Task & 1.000 & $<0.0001$ \\
Magnitude of Effort & 1.000 & $<0.0001$ \\
Total Score & 0.960 & $<0.0001$ \\
\hline
\end{tabular}

\section{Discussion}

This study demonstrates the successful development of the Brazilian version of the Modified Dyspnea Index, originally developed in English for a North American population. The process for cultural adaptation of the MDI to a Brazilian population adopted in this study, complied with the approach suggested by Guillemin ${ }^{(14)}$ and Beaton(15), considering both linguistic and cultural features.

More specifically, assuring adequate adaptation requires demonstrating that the translated instrument closely resembles the original instrument regarding four specific parameters: semantic (i.e., the words mean the same things on both versions), idiomatic (i.e., the terms and colloquialisms are similar), cultural (i.e., the activities and context generalize across the different cultures), and conceptual (i.e., that the concept of dyspnea exists and is similar in both the original and 
target culture). The process by which the Brazilian version of the MDI was prepared was attentive to and rigorously satisfied these criteria for equivalence of the original and translated instruments ${ }^{(14,19)}$.

Several features make the adaptation of the original MDI for use in the Brazilian population more difficult. For example, some of the tasks described in the American instrument were not compatible with the Brazilian experience and required the activities' replacement by other metabolic equivalents common in daily Brazilian reality (replacing baseball by soccer for example). Indeed, the MDI is complex with subscores and total scores, making explanation in the user's manual particularly important.

Given this complexity and the fact that, to our knowledge, the MDI has not been adapted to other cultures yet, special attention was given to the development and validation of a user's guide to accompany the translated instrument, target to health professionals.

Among different instruments used for dyspnea assessment, the Borg scales (original and modified)(5), the Visual Analogue Scale ${ }^{(4)}$ and the Medical Research

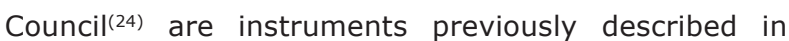
the Brazilian context and applied to assess cardiac patients. None of these instruments, however, explores the impact and limitations causes by profound and extensive dyspnea in different context, which is the goal of the MDI.
Finally, while adaptation of the MDI for use in a Brazilian population has been undertaken with rigor and in compliance with available guidelines for such work, further validation of this work will depend on further use of the instrument in Brazil. Further research will permit the assessment of the instrument's convergent validity, by testing its correlation with the perceived effort evaluated by other measures as the Modified Borg scale; quality of life (Minnesota Living with Heart Failure Questionnaire) and assessment of respiratory muscle strength. The MDI will allow health professional to estimate the evolution of dyspnea with greater precision and thus direct the planning of cardiovascular rehabilitation in the Brazilian context.

\section{Conclusion}

The cultural adaptation process of the Modified Dyspnea Index to the Brazilian culture was performed with great methodological rigor, adding the constitution of a second expert committee to the habitual adaptation steps with a view to assessing the metabolic equivalents of the replaced activities and the elaboration of a User's Guide, in order to standardize its application by different health professionals. The applicability of both instruments was assessed as satisfactory and the assessment of its intra-observer equivalence indicated a satisfactory agreement level.

\section{References}

1. Chizner MA. The diagnosis of heart disease by clinical assessment alone. Curr Prob Cardiol. 2001;26(5):290-380.

2. American Thoracic Society. Dyspnea: Mechanism, Assessment, and Management: A consensus statement. Am J Respir Crit Care Med. 1999;159:321-40.

3. Clará CP. Evalución de la disnea y de la calidad de vida relacionada con la salud. Arch Bronconeumol. 2007;43(3):2-7.

4. Eakin EG, Sassi-Dambron EE, Ries AL, Kaplan RL. Reliability and validity of dyspnea measures in patients with obstructive lung disease. Int J Behav Med. 1995; 2:118-34.

5. Borg GAV. Psychophysical bases of perceived exertion. Med Sci Sports Exerc. 1982;14(5):377-81.

6. Gift AG, Narsavage G. Validity of numeric rating scale as a measure of dyspnea. Am J Crit Care. 1998;7(3):200-4.

7. Lewis RJ, Thompson DR, Martin CR, Stuckey N, Devlen J, Michaelson $S$, et al. Validation of the cardiovascular limitation and symptoms profile (CLASP) in chronic stable angina. J Cardiopulm Rehabil. 2002;22(3):184-91.

8. Guyatt GH, Nogradi S, Halcrow S, Singer J, Sullivan MJ, Fallen EL. Development and testing of a new measure of health status for clinical trials in heart failure. J Gen Intern Med. 1989;4(2):101-7.
9. McGavin CR, Artvinli M, Naoe H, McHardy GJR. Dyspnea, disability, and distance walked: comparison of estimates of exercise performance in respiratory disease. $\mathrm{Br}$ Med $\mathrm{J}$. 1978;2:241-3.

10. Mahler DA, Weinberg DH, Wells CK, Feinstein AR. The measurement of dyspnea. Contents, interobserver agreement, and physiologic correlates of two new clinical indexes. Chest. 1984;85(6):751-8.

11. Stoller JK, Ferranti R, Feinstein. Further specification and evaluation of a new clinical index for dyspnea. Am Rev Respir Dis. $1986 ; 134: 1129-34$.

12. O'Donnell DE, Chau LKL, Webb KA. Qualitative aspects of exertional dyspnea in patients with interstitial lung disease. J Appl Physiol. 1998;84:2000-9.

13. Brancaleone P, Perez T, Robin S, Neviere R, Wallaert B. Clinical Impact of inspiratory muscle impairment in sarcoidosis. Sarcoidosis Vasc Diffuse Lung Dis. 2004;21(3):219-27.

14. Guillemin F, Bombardier C, Beaton D. Cross-cultural adaptation of health-related quality of life measures: literature review and proposed guidelines. J Clin Epidemiol. $1993 ; 46(12): 1417-32$ 
15. Beaton DE, Bomcardier C, Guillemin F, Bosi Ferraz M. Guidelines for the process of cross-cultural adaptation of selfreports measures. Spine. 2000;25(24):3186-91.

16. Alexandre NM, Guirardello EB. Adaptación cultural de instrumentos utilizados en salud ocupacional. Rev Panam Salud Publica. 2002;11(2):109-111.

17. Institute for Work \& Health. Recommendations for the Cross-Cultural Adaptation of the DASH \& QuickDASH Outcome Measures [Internet]. 2007 [acesso $10 \mathrm{dez}$ 2009]. 45 p. Disponível em: http://www.dash.iwh.on.ca/assets/images/ pdfs/X-CulturalAdaptation-2007.pdf.

18. Guillemin F. Cross-cultural Adaptation and Validation of Health Status Measures. Scand J Rheumatol. 1995;24(2):61-3. 19. Hutchinson A, Bentzen N, Konig-Zanhn C. Cross cultural health outcome assessment: a user's guide. Groningen: European Research Group on Health Outcomes; 1997.
20. Farinatti PTV. Apresentação de uma versão em português do Compêndio de Atividades Físicas: uma contribuição aos pesquisadores e profissionais em fisiologia do exercício. Rev Bras Fisiol Exerc. 2003;2(2):177-208.

21. Lynn, MR. Determination and Quantification of Content Validity. Nurs Res. 1986; 35(6):382-5.

22. Waltz CW, Bausell RB. Nursing research: Design, statistics and computer analysis. Philadelphia: F. A. Davis; 1981.

23. Alexandre NMC, Coluci MZO. Validade de conteúdo nos processos de construção e adaptação de instrumentos de medidas. Ciênc Saúde Colet. 2010 no prelo.

24. Kovelis D, Segretti NO, Probst VS, Lareau SC, Brunetto AF, Pitta F. Validação do Modified Pulmonary Functional Status and Dyspnea Questionnaire e da escala do Medical Research Council para o uso em pacientes com doença pulmonar obstrutiva crônica no Brasil. J Bras Pneumol. 2008;34(12):1008-18.

\section{Anexo}

\section{Índice de Dispnéia Modificado (MDI) - Critérios de Classificação}

\section{Critérios para atribuição do grau: Comprometimento funcional no trabalho}

Grau 4 - Nenhum (sem) Comprometimento: O paciente é capaz de realizar as atividades habituais associadas ao trabalho sem apresentar falta de ar (dispnéia). Para ser classificado como grau 4, o paciente deve:

(a) não ter mudado de emprego (ou trabalho), nem ter modificado as atividades profissionais por causa da falta de ar (dispnéia).

(b) não ter diminuído, por causa da falta de ar (dispnéia), o número de horas/semana de trabalho, nem ter diminuído as atividades realizadas no trabalho por serem muito exaustivas, seja eliminando determinadas tarefas do mesmo trabalho ou mudando sua ocupação para uma que exija menos esforço físico.

Grau 3 - Comprometimento Leve: O paciente reconhece que a falta de ar (dispnéia) tem feito com que ele (ela) altere suas atividades de trabalho.

Embora nenhuma responsabilidade profissional tenha sido completamente abandonada por causa da falta de ar (dispnéia), pelo menos uma tarefa relacionada ao trabalho é realizada mais lentamente por causa da falta de ar (dispnéia).

Grau 2 - Comprometimento Moderado: O paciente:

(a) manteve o mesmo trabalho e a mesma quantidade de horas trabalhadas/semana que realizava antes do aparecimento da falta de ar (dispnéia), porém, por causa da falta de ar (dispnéia), ele (ela) abandonou completamente pelo menos uma das tarefas que exercia como parte daquele trabalho, ou

(b) alterou seu trabalho para uma atividade menos exaustiva porque a falta de ar (dispnéia) interferia nas atividades, ou

(c) manteve seu trabalho anterior (por exemplo o(s) trabalho(s) que realizava antes do aparecimento da falta de ar (dispnéia), mas diminuiu o número de horas/semana trabalhadas naquela função.

As categorias (b) e (c) não são mutuamente exclusivas, uma vez que o paciente diminui a quantidade de horas trabalhadas naquela função, mas acrescenta uma segunda atividade, menos exaustiva, por razões financeiras. Essa situação é também classificada como grau 2.

Grau 1 - Comprometimento Grave: O paciente parou de trabalhar por causa da falta de ar (dispnéia). Esta categoria inclui:

(a) pacientes que se aposentaram precocemente por causa da falta de ar (dispnéia). e que, apesar do desejo de trabalhar, não encontraram um emprego (ou trabalho) realmente adequado por causa da falta de ar (dispnéia).

(b) pacientes que pararam de trabalhar por causa da aposentadoria compulsória (por idade), e que também apresentam falta de ar (dispnéia), são classificados de acordo com o nível de comprometimento de seu trabalho por causa da falta de ar (dispnéia) antes da aposentadoria.

Exemplo: Um trabalhador da construção civil que deixou a equipe de trabalho para assumir uma atividade administrativa por causa da falta de ar (dispnéia) e que agora atingiu a idade para se aposentar seria classificado como grau 2, para "comprometimento funcional no trabalho", ao invés de grau 1. 
Opções para classificação de grau (caso a numérica não seja suficiente) de acordo com as seguintes informações:

W: Quantidade Indeterminada (Incerta). O paciente apresenta comprometimento por causa da falta de ar (dispnéia), mas o nível não pode ser especificado porque não há detalhes suficientes.

X: Desconhecido. Informação não disponível.

Y: Comprometimento por razões outras que não a falta de ar (dispnéia). O grau Y é atribuído se o paciente apresenta como principal limitação outra incapacidade, diferente da falta de ar (dispnéia); como por exemplo, dor torácica, afecção do quadril ou algum outro comprometimento musculoesquelético.

Favor descrever a natureza da(s) outra(s) afecção(ões) limitante(s):

Z: O paciente está desempregado desde antes do aparecimento do sintoma de falta de ar (dispnéia) e desde então não procurou emprego.

Exemplo: Um paciente, que não é um chefe de família e que não pretendia encontrar um emprego mesmo antes do aparecimento da falta de ar (dispnéia).

Para os pacientes que não estavam trabalhando quando a falta de ar (dispnéia) começou, mas que apresentaram o sintoma quando começaram a trabalhar, e que consideraram a falta de ar (dispnéia) como um fator determinante em seu trabalho, classificar como grau 2.

Atenção: caso a classificação do paciente tiver mais de um grau, optar sempre pelo menor grau.

\section{Critérios para atribuição de grau: Comprometimento funcional para realização das atividades domésticas}

Grau 4 - Nenhum Comprometimento: O paciente é capaz de realizar suas atividades domésticas habituais sem apresentar falta de ar (dispnéia); não há redução do número ou limitação do tipo de atividades domésticas realizadas, e nenhuma redução no ritmo em que as atividades são realizadas.

Grau 3 - Comprometimento Leve: O paciente reconhece que a falta de ar (dispnéia) tem-no levado a alterar suas atividades domésticas habituais de uma das seguintes formas:

(a) Embora nenhuma atividade habitual tenha sido completamente abandonada como conseqüência da falta de ar (dispnéia), várias (mas não todas) atividades são realizadas mais lentamente.

(b) Embora o paciente mantenha todas as suas atividades, pelo menos uma atividade é realizada com menor freqüência por causa da falta de ar (dispnéia).

Exemplo: Um fiel torcedor de futebol que agora, por causa da falta de ar (dispnéia), vai assistir apenas de vez em quando a um jogo, ao invés de ir a todos os jogos como fazia anteriormente, seria classificado como apresentando comprometimento leve (grau 3) no item comprometimento funcional em casa.

Grau 2 - Comprometimento Moderado: A falta de ar provocou no paciente uma limitação das atividades, pelo menos de uma das seguintes formas:

(a) várias (mas não todas) as atividades foram completamente abandonadas por causa da falta de ar (dispnéia), e/ou

(b) a maioria ou todas as atividades habituais são realizadas mais lentamente por causa da falta de ar (dispnéia). Exemplo: Um paciente costumava ir á igreja regularmente antes do aparecimento da falta de ar (dispnéia), mas não vai mais ao teatro devido à sua incapacidade pulmonar. Entretanto, como ele ainda mantém sua atividade de lazer, como trabalhar com madeira (carpintaria em casa (apesar de fazê-las mais lentamente), ele deve ser classificado como grau 2.

Grau 1 - Comprometimento Grave: A falta de ar (dispnéia) fez com que o paciente abandonasse a maior parte ou todas as suas atividades habituais. Os exemplos incluiriam:

(a) O paciente que fica com muita falta de ar (dispnéia) ao sair de casa sem ajuda.

(b) O paciente que, como conseqüência falta de ar (dispnéia), passou a depender do cônjuge ou de alguém para ajudá-lo a realizar as tarefas, como fazer compras, cozinhar e limpar a casa, e que pode ainda precisar de ajuda para vestir-se ou tomar banho.

\section{Opções para classificação de grau (caso a numérica não seja suficiente) de acordo com as seguintes informações:}

W: Quantidade Indeterminada

X: Desconhecido

Y: Comprometida por razões outras que não a falta de ar (dispnéia)

Favor descrever a natureza da(s) outra(s) condição(ões) limitante(s):

ATENÇÃO: CASO A CLASSIFICAÇÃo do PACIENTE TIVER MAIS DE UM GRAU, OPTAR SEMPRE PELO MENOR GRAU. 
III. Instruções para atribuição do grau de comprometimento funcional composto

\begin{tabular}{|c|c|c|}
\hline $\begin{array}{l}\text { Grau de comprometimento } \\
\text { funcional no trabalho }\end{array}$ & $\begin{array}{l}\text { Grau de comprometimento } \\
\text { funcional em casa }\end{array}$ & Grau composto de comprometimento funcional \\
\hline 2,3 , ou 4 & 2,3 , ou 4 & $\begin{array}{l}\text { O menor grau na categoria "trabalho" ou "casa" torna-se o grau composto; } \\
\text { para graus idênticos nas categorias "trabalho" e "casa", o grau composto } \\
\text { será este mesmo grau. }\end{array}$ \\
\hline 1 & 2,3, ou 4 & \multirow{2}{*}{ Atribuir grau composto como Grau 1, ou comprometimento grave. } \\
\hline 2,3, ou 4 & 1 & \\
\hline 1 & 1 & $\begin{array}{l}\text { Atribuir grau composto como Grau 0, ou comprometimento muito grave. } \\
\text { Os indivíduos classificados como grau } 0 \text { não estarão mais trabalhando } \\
\text { devido à falta de ar (dispnéia) (ou seja, grau funcional } 1 \text { no trabalho) e serão } \\
\text { gravemente prejudicados em suas atividades domésticas habituais. }\end{array}$ \\
\hline 2,3, ou 4 & $w, x$, ou y & Atribuir o grau funcional no trabalho como o grau composto. \\
\hline$w, x, y$, ou z & $1,2,3$, ou 4 & Atribuir o grau funcional em casa como o grau composto. \\
\hline$w, x, y$, ou $z$ & w, x, ou y & $\begin{array}{l}\text { Atribuir a combinação de duas letras como um grau composto (com o grau } \\
\text { atribuído no "trabalho" sendo colocado em primeiro lugar) de cada um } \\
\text { dos graus individuais; ou seja, o grau W atribuído no "trabalho" e o grau X } \\
\text { atribuído em "casa" seria o grau composto WX, etc. }\end{array}$ \\
\hline
\end{tabular}

\section{Critérios para atribuição de grau: Amplitude da tarefa}

Grau 4 Extraordinária: Apresenta falta de ar (dispnéia) somente quando realiza atividade fora do comum, tal como:

- carregar objetos muito pesados em nível plano;

- carregar objetos mais leves em subidas ou escadas;

- correr.

Grau 3 Importante: Apresenta falta de ar (dispnéia) somente quando realiza atividades de grande porte, tais como:

- subir a pé ladeiras acentuadas;

- subir dois lances ou mais de escada;

- carregar uma sacola pesada de compras em nível plano.

Grau 2 Moderada: Começa a apresentar falta de ar (dispnéia) ao realizar tarefas moderadas tais como:

- subir até dois lances de escada;

- subir a pé ladeiras progressivas (gradual);

- caminhar rapidamente em nível plano;

- carregar uma carga leve em nível plano

Grau 1 Leve: Começa a apresentar falta de ar (dispnéia) ao realizar atividades leves, tais como:

- caminhar em nível plano com outras pessoas da mesma idade;

- caminhar em casa até o banheiro

- tomar banho;

- vestir-se;

- escovar os dentes

Grau 0 Nenhuma (sem) tarefa: Começa a apresentar falta de ar (dispnéia) mesmo sem realizar nenhuma atividade, como:

- enquanto está sentado e/ou deitado;

- enquanto está em pé sem se movimentar.

Opção para classificação de grau (caso a numérica não seja suficiente) de acordo com as seguintes informações:

W: Quantidade Indeterminada

X: Desconhecido

Y: Comprometida por razões outras que não a falta de ar (dispnéia)

Favor descrever a natureza da(s) outra(s) condição(ões) limitante(s):

ATENÇÃO: utilizar como referência última atividade à qual o paciente respondeu sim (ou não realiza por causa da dispnéia) 


\section{Critérios para atribuição de grau: Amplitude de esforço}

Para a tarefa mais cansativa (vigorosa) que o paciente pode executar (pelo menos por cinco minutos):

Grau 4: Tarefa realizada rapidamente sem necessidade de pausa por causa da falta de ar (dispnéia), nem mesmo diminuição do ritmo para descansar.

Grau 3: Tarefa realizada mais devagar, mas sem pausa ou parada para recuperar o fôlego.

Grau 2: Tarefa realizada mais devagar com raras pausas (uma ou duas) para recuperar o fôlego antes de terminar as tarefas ou abandoná-las completamente.

Grau 1: Tarefa realizada mais devagar e com muitas paradas ou pausas antes de concluir ou abandonar a tarefa.

Grau 0: O paciente apresenta falta de ar (dispnéia), em repouso, ou quando está sentado ou deitado.

Opções para classificação de grau (caso a numérica não seja suficiente) de acordo com as seguintes informações:

\section{W: Quantidade Indeterminada}

X: Desconhecido

Y: Comprometida por razões outras que não a falta de ar (dispnéia)

Favor descrever a natureza da(s) outra(s) condição(ões) limitante(s):

Note que a condição outra, que não a falta de ar (dispnéia), que limita a condição mais exaustiva para o paciente, não precisa ser a mesma incapacidade que limita as outras atividades descritas neste questionário. Por exemplo, o paciente, cuja angina ocorre somente quando ele realiza atividade exaustiva, pode apresentar pouca limitação funcional ao realizar um trabalho sedentário (Grau 4 para "comprometimento funcional no trabalho"), mas pode sentir limitação para realizar atividades mais extenuantes devido à angina (Grau Y em "magnitude do esforço": dor torácica).

Received: May $5^{\text {th }} 2010$

Accepted: Ago. $25^{\text {th }} 2010$ 